\title{
A RE-ASSESSMENT OF THE MASS BALANGE OF THE LAMBERT GLACIER DRAINAGE BASIN, ANTARCTICA
}

\author{
By N. F. MaINTYRE* \\ (Scott Polar Research Institute, University of Cambridge, Cambridge CB2 1ER, England)
}

\begin{abstract}
Re-definition of the interior drainage basin of Lambert Glacier, using the most recent sources of ice-surface elevations, has shown its area to be $902000 \mathrm{~km}^{2}$, that is, $17 \%$ less than previous estimates. Landsat imagery of the steepest sloping part of the basin shows there is bare ice over an area of $56000 \mathrm{~km}^{2}$. Other evidence also indicates exceptionally low mass inputs and the distribution of accumulation rates has been up-dated. The result is a positive mass balance for the interior basin $\left(+2 \mathrm{Gt} \mathrm{a}^{-1}\right)$ and error limits which fall below zero. This is $47 \%$ less than the most recent calculation and illustrates the difficulty in deriving mass budgets in regions where data are scarce.
\end{abstract}

RÉsumé. Redéfinition du bilan de masse du bassin versant du Lambert Glacier, Antarctique. Une redéfinition du bassin versant du Lambert Glacier à l'aide des plus récentes sources de l'altitude de la glace a montré que sa surface est de $902000 \mathrm{~km}^{2}$, c'est-à-dire $17 \%$ de moins que les estimations antérieures. L'imagerie Landsat de la partie la plus inclinée du bassin montre qu'il y a $56000 \mathrm{~km}^{2}$ de glace nue. D'autres évidences indiquent d'exceptionnellement faibles apports de glace et une distribution

\section{INTRODUCTION}

That part of the Antarctic which drains into the Amery Ice Shelf has long been of interest to glaciologists because of its size. It forms a prominent and distinctive feature of the Antarctic ice sheet and has been identified as the continent's fourth largest drainage system (Giovinetto, 1964). Its main tributary is Lambert Glacier, which flows through the rift between the Prince Charles Mountains and the Mawson Escarpment. There, it is over $50 \mathrm{~km}$ wide and reaches a thickness of $2500 \mathrm{~m}$ (Morgan and Budd, 1975). Several attempts have been made to assess the mass balance of the Amery-Lambert drainage system (Mellor, 1959, 1964; Gi ovinetto, 1964, [1970]; Budd and others, 1967; Allison, 1979) and all have calculated positive mass budgets. Although based on conservative estimates of accumulation rates, a mean surface elevation rise of $+0.04 \mathrm{~m} \mathrm{a}^{-1}$ in the Amery-Lambert system (A11 ison, 1979) has supported the results of modelling the East Antarctic ice sheet (Budd and McInnes, [ $\left.{ }^{\mathrm{C}} 1978\right]$ ) and has been taken to indicate that the system may, at present, be undergoing a post-surge build-up.

These mass-balance studies have all been hindered by the scarcity of data for this remote part of the Antarctic, particularly of accumulation rates in the interior of the drainage basin. The purpose of this paper is to re-assess the budget of this part of the drainage basin of Lambert Glacier in the light of new data concerning its area and the accumulation rates within it. The interior drainage basin is defined here as the accumulation area which drains into the Lambert Glacier system delimited by the eleven ice-movement stations reported by Allison (1979).

\section{AREA OF THE INTERIOR DRAINAGE BASIN}

Previous studies have been inhibited by the sparseness of surface elevation data with which to delimit the interior drainage basin of Lambert Glacier. Errors have typically been estimated to be 20 to $30 \%$

*Now at Department of Physics and Astronomy, University College London, Mullard Space Science Laboratory, Holmbury St Mary, Dorking, Surrey RH5 6NT, England. d'accumulation plus recente. Le résultat est un bilan positif pour l'intérieur du bassin $\left(+2 \mathrm{Gta}^{-1}\right)$ et des limites d'erreur qui tombent au-dessous de zéro. Ceci est de $47 \%$ inférieur aux plus récentes déterminations et illustre la difficulté à déduire des bilans de masse pour des régions où les données sont dispersées.

Zusammenfassung. Eine Neuberechnung der Massenbilanz im Abflussbecken des Lambert Glacier, Antarktika. Eine Neuabgrenzung des inneren Abflussbeckens des Lambert Glacier auf der Grundlage der neuesten Eishöhenbestimmungen ergab deren Fläche zu $902000 \mathrm{~km}^{2}$, also $17 \%$ weniger als früher abgeschätzt. Landsat-Bilder vom steilsten Teil des Beckens zeigen dort das Vorhandensein blanken Eises über eine Fläche von $56000 \mathrm{~km}^{2}$. Andere Hinweise deuten ebenfalls auf aussergewöhnlich niedrigen Massenzustrom, weshalb die Verteilung der Akkumulationsrate neu bestimmt wurde. Das Ergebnis ist eine positive Massenbilanz für das innere Becken $(+2 \mathrm{Gt}$ pro Jahr) mit Fehlergrenzen unter Null. Dies ist $47 \%$ weniger als die jüngste Berechnung und zeigt die Schwierigkeit der Massenbilanzbestimmung in Gegenden, für die nur wenige Daten vorliegen.

(Mellor, 1959, 1964; Giovinetto, 1964, [1970]; Budd and others, 1967). The most recent estimate of $1.09 \times 10^{6} \mathrm{~km}^{2} \pm 20 \%$ (Allison, 1979) was based on the American Geographical Society 1 : 5000000 map of Antarctica published in 1970. This was modified with data from airborne radio echo-sounding (Morgan and Budd, 1975) and oversnow survey (Allison, 1979) by the Australian National Antarctic Research Expeditions. Surface elevations were also available from traverses by the Japanese Antarctic Research Expeditions which intersected the south-western limits of the drainage basin (Fujiwara and others, 1971; Shimizu, 1977). However, there was a complete lack of data in the central parts of the drainage basin.

The present study used the most recent compilation of ice surface elevations in the Antarctic (Drewry, [C $\left.{ }^{C} 1983\right]$ ) to redefine the boundaries of the interior drainage basin. This includes altimetry from two sources (radio echo-sounding and constant-density balloons) not available to previous mass-balance studies. The distribution of these data in the interior drainage basin is shown in Figure 1 with the general ice-sheet surface, contoured at an interval of $500 \mathrm{~m}$.

Surface elevations were available along $5100 \mathrm{~km}$ of flight track completed during the joint radio echosounding programme of the National Science Foundation, the Scott Polar Research Institute, and the Technical University of Denmark (Drewry and others, 1982). These cover the southern and south-eastern parts of the drainage basin. The method used to calculate elevations, based on barometric altimetry, has been described by Drewry and others (1982). Errors in areas away from control points, such as in the interior drainage basin, are estimated to be better than $50 \mathrm{~m}$ and, at best $30 \mathrm{~m}$ (Drewry, [ $\left.{ }^{C} 1983\right]$ ). Some 280 elevations, widely distributed across the drainage basin, are also available from constant-density, superpressure balloons which opportunely drifted over the Antarctic during the Tropical Wind Energy and Reference Level Experiment (TWERLE) in 1975-76. The method and results have been described by Levanon (1982). Worst-case errors are thought to be of the order of $\pm 60 \mathrm{~m}$.

The combination of these two new sources and those 


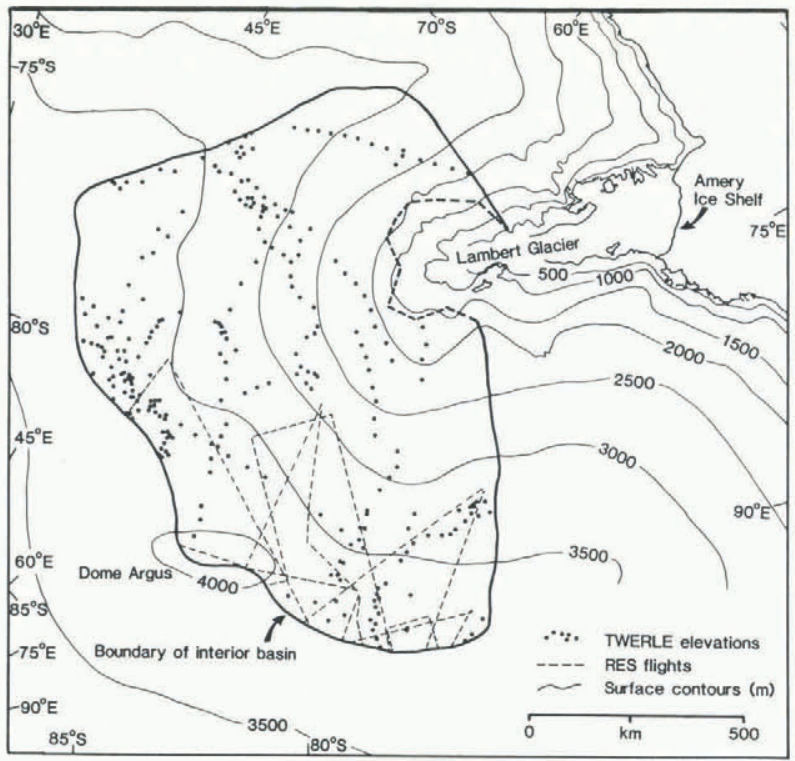

Fig. 1. Delimitation of the interior drainage basin of the Lambert Glacier system (redrawn from Drewry, [c1983]). The distribution of ice surface elevations from TWERLE (dots) and radio echo-sounding (dashed lines) is also shown.

available to previous workers has enabled a more precise delimitation of the area contributing to the discharge of ice through the network of ice-movement stations reported by Allison (1979). Flow lines were constructed from a 1 : 6000000 map contoured every $100 \mathrm{~m}$ (Drewry, $\left.\left[{ }^{C} 1983\right]\right)$ on the principle that, over distances several times the ice thickness, ice flow is normal to the trend of the contours. The resulting drainage basin has an area of $902000 \mathrm{~km}^{2}$. It is difficult to place an error on this figure but, given that the margin of the drainage basin has been located to within $\pm 25 \mathrm{~km}$, the actual area is likely to be between 813000 and $994000 \mathrm{~km}^{2}$. This represents an error of $\pm 10 \%$. The significance of this re-calculation of the area is that it is $17 \%$ less than that defined by Allison (1979) which was used to estimate the mass balance.

\section{PATTERN OF ACCUMULATION}

Accumulation data within the drainage basin are also sparse, being largely confined to traverse routes along the southern periphery. In some areas, where interpolation between adjacent areas is necessary, interpretations have differed significantly (Bull, 1971; Kotlyakov and others, 1974). Allison (1979) modified the available data to account for the low values recorded at most of the ice-movement stations; this resulted in the $100 \mathrm{~kg} \mathrm{~m}^{-2} \mathrm{a}^{-1}$ isopleth passing north of the head of Lambert Glacier. Despite these conservative values for the accumulation rate, there are several sources which suggest that the interior drainage basin is an area of exceptionally low accumulation. This may in part be the cause of the imbalance between accumulation within the basin and the discharge of ice from it (Robin, 1983).

Figure 2 shows a band 7 multispectral scanner (MSS) Landsat image centred at lat. $76^{\circ} 15^{\prime} \mathrm{S}$., long. $68^{\circ} 18^{\prime} \mathrm{E} ., 200 \mathrm{~km}$ south-east of the outlying nunataks of Mawson Escarpment. As well as substantial surface undulations and crevasse trains due to ice flow over the irregular subglacial Gamburtsev Mountains, there are considerable areas of what is interpreted to be bare ice (darker tones) interspersed with variable amounts of firn. Visual confirmation of this interpretation comes from comparison with Landsat imagery

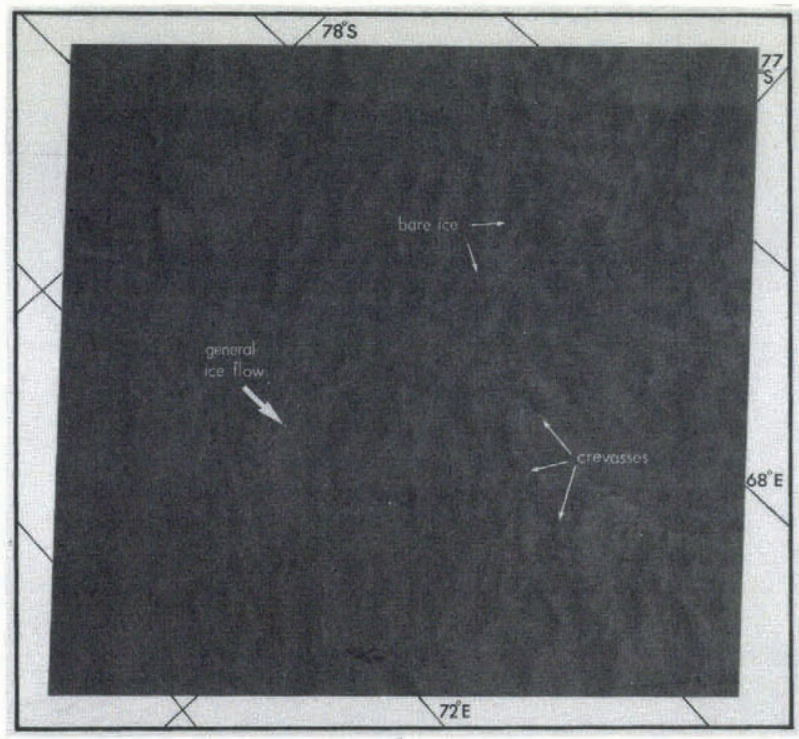

Fig. 2. Band ? Landsat MSS image centred at lat. $76^{\circ} 15^{\prime} \mathrm{S}$. long. $68^{\circ} 18^{\prime} \mathrm{E}$. in the region of the subglacial Gamburtsev Mountains. Patches of bare ice (darker tones) can be seen as well as surface undulations and crevassed areas. Sun angle is $21^{\circ}$. Path 126, row 115. 1479-02223.

of blue ice in the Queen Fabiola Mountains area (Williams and others, 1983) and near Allan Hills, Victoria Land. Similar patterns of tonal variations across and between undulation crests occur in all three areas. Further confirmation could be achieved with an analysis of spectral response patterns derived from digital Landsat data.

Compilation of a mosaic of 16 MSS images, covering most of the drainage basin up to $500 \mathrm{~km}$ inland of Lambert Glacier, enabled the area of bare ice to be mapped (Fig. 3). Since the bare ice occurs in isolated patches which form a complex pattern, this was taken as the region in which more than half of the terrain was composed of exposed ice. It was found to cover $56000 \mathrm{~km}^{2}$, that is, over $6 \%$ of the area of the interior drainage basin.

Blue-ice areas have been attributed to ablation by sublimation, wind scouring, and surface polishing by wind-driven snow (Williams and others, 1983). They are, therefore, most likely to occur in areas of strong katabatic winds. Where mean surface slopes are greater than 0.002 radians, katabatic forces tend to exceed considerably those arising from synoptic pressure gradients (Ball, 1960). Within the drainage basin of Lambert Glacier, these gradients, calculated over $50 \mathrm{~km}$ segments, are exceeded below elevations of 3500 to $3800 \mathrm{~m}$. In the area reported to contain blue ice, which is between 2000 and $3100 \mathrm{~m}$, slopes range from 0.003 to 0.008 radians, with a mean of 0.0045 radians. This is the most steeply sloping part of the interior drainage basin and hence that which is most likely to be subject to the strongest katabatic winds. Although katabatic winds are funnelled downslope by topographic embayments, Parish (1981) reports that they are deflected by 30 to $50^{\circ}$ left of the fall line by the Coriolis force. This can be seen in the present case where the main axis of the zone of bare ice lies approximately $30^{\circ}$ to the left of the maximum regional slope. That these winds are capable of ablating the ice-sheet surface at a sufficient rate to produce blue ice is suggested by the observation at Mizuho Station (lat. $70^{\circ} 41^{\prime} 53^{\prime \prime} \mathrm{S}$., long. $44^{\circ} 19^{\prime} 54^{\prime \prime} \mathrm{E} ., 2230 \mathrm{~m}$ above sea-level). Here, sublimation (54 kg m-2 a $\mathrm{ag}^{-1}$ ) is significant in reducing the annual accumulation (Fujii and Kusonoki, 1982). Gradients on the slope of the Mizuho Plateau with 


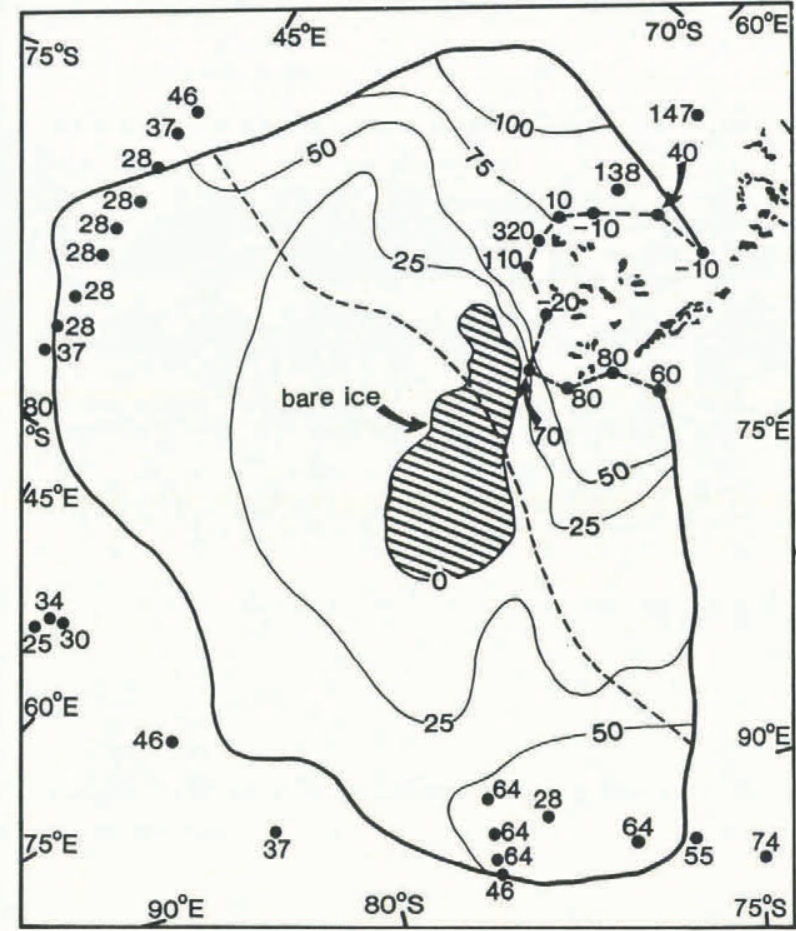

Fig. 3. Revised distribution of accumulation rates in the interior drainage basin of the Lambert Glacier system. Area of bare ice is shaded. Contours have been extrapolated between the bare ice and measured values on the basis of brightness temperatures. The $50 \mathrm{~kg} \mathrm{~m}-2 a^{-1}$ isopleth of Allison (1979) is shown (dashed $l_{i n e}$. Measured accumulation rates are given for the 11 ice-movement stations (Allison, 1979) and previously published values near the periphery. Outcrops near Lambert Glacier are shown as black areas.

strong katabatic wind are directly comparable with those in the Lambert Glacier drainage basin. It is therefore possible that these very high rates of sub1 imation also occur in the catchment area of Lambert Glacier and are in part responsible for the exposed blue ice indicated by Landsat imagery.

The notion that the entire interior drainage basin of Lambert Glacier is an area of exceptionally low accumulation is also supported by an analysis of passive microwave radiometry (Zwally and Gloersen, 1977). Brightness temperatures of polar firn are closely although complexly related to mean annual temperatures and to accumulation. The anomalously low values found throughout the drainage basin were attributed by

Zwally and Gloersen (1977) to particularly low accumulation rates, thereby supporting the suggestion that sublimation by katabatic winds across the regionally steep slopes may significantly reduce the mass input to the basin.

On the basis of the above observations, the distribution of accumulation rates was re-contoured as shown in Figure 3. Even though ablation rates of up to $60 \mathrm{~kg} \mathrm{~m}^{-2} \mathrm{a}^{-1}$ have been recorded for blue ice areas in the Queen Fabiola Mountains (Yokoyama, 1978), the present delimitation of bare ice includes intervening areas of firn. A mean net accumulation of zero has been used to account for this local variability. Accumulation rates in the rest of the drainage basin have been contoured at an interval of $25 \mathrm{~kg} \mathrm{~m}^{-2} \mathrm{a}^{-1}$ using brightness temperatures to provide an empirical extrapolation between the bare ice and the few known values at the periphery of the catchment area. The contouring attempts to show the regional patterns in accumulation and individual values have not been honoured in all cases. Local variability may, in part, be associated with the presence of areas of outcrop which significantly affect the heat balance and wind pattern at the ice-sheet surface (Allison, 1979).

\section{RE-CALCULATION OF THE MASS BUDGET}

Using the distribution of accumulation rates shown in Figure 3 , the annual mass input to the interior drainage basin was found to be $32 \mathrm{Gt} \mathrm{a}^{-1}$. This represents a $47 \%$ reduction from the figure of $60 \mathrm{Gt} \mathrm{a}^{-1}$ calculated by Allison (1979). There is only a $6 \%$ imbalance between input to the basin and discharge from it as opposed to the previous estimate of $100 \%$, thereby allowing for a balanced mass budget. The mean rate of mass input across the drainage basin is $36 \mathrm{~kg} \mathrm{~m}^{-2} \mathrm{a}^{-1}$. Table I gives details of the mass budget which, for comparative purposes, has been extended to include the Lambert Glacier system and the

TABLE I. RE-CALCULATION OF THE MASS BALANCE OF LAMBERT GLACIER ON THE BASIS OF THE REVISED AREA AND ACCUMULATION RATES SHOWN IN FIGURES 1 AND 3

(Bracketed values are those of Allison (1979).)

\begin{tabular}{|c|c|c|c|}
\hline & $\begin{array}{l}\text { Interior } \\
\text { drainage } \\
\text { basin }\end{array}$ & $\begin{array}{l}\text { Lambert } \\
\text { Glacier } \\
\text { system }\end{array}$ & $\begin{array}{l}\text { Total } \\
\text { drainage } \\
\text { basin }\end{array}$ \\
\hline Inflow (Gt $a^{-1}$ ) & $\dot{(-)}$ & $\begin{array}{l}30 \\
(30)\end{array}$ & $\overline{(-)}$ \\
\hline $\begin{array}{c}\text { Gain in basin } \\
\left(\text { Gt } a^{-1}\right)\end{array}$ & $\left(\begin{array}{l}32 \\
60\end{array}\right)$ & $\left(\begin{array}{l}-7 \\
-7\end{array}\right)$ & $\begin{array}{l}25 \\
(53)\end{array}$ \\
\hline Outflow (Gt $a^{-1}$ ) & $\left(\begin{array}{l}30 \\
(30)\end{array}\right.$ & $\begin{array}{l}11 \\
(11)\end{array}$ & ( 11 (1) \\
\hline Budget (Gt $a^{-1}$ ) & $\begin{array}{c}+2 \\
(+30)\end{array}$ & $\begin{array}{c}+12 \\
(+12)\end{array}$ & $\begin{array}{l}+14 \\
(+42)\end{array}$ \\
\hline $\begin{array}{l}\text { Budget limits } \\
\left(\text { Gt } a^{-1}\right)\end{array}$ & $\begin{array}{l}-11,+16 \\
(+3,+79)\end{array}$ & $\begin{array}{l}-4.5,+28 \\
(-4.5,+28)\end{array}$ & $\begin{array}{r}0,+25 \\
(+9,+89)\end{array}$ \\
\hline Area (thousand $\mathrm{km}^{2}$ ) & $\begin{array}{c}902 \\
(1090)\end{array}$ & $\begin{array}{c}62 \\
(62)\end{array}$ & $\begin{array}{c}964 \\
(1152)\end{array}$ \\
\hline $\begin{array}{l}\text { Mean annual sur- } \\
\text { face level change } \\
\left(\mathrm{m} \mathrm{a} \mathrm{a}^{-1} \text { water }\right)\end{array}$ & $\begin{array}{r}+0.002 \\
(+0.03)\end{array}$ & $\begin{array}{c}+0.19 \\
(+0.19)\end{array}$ & $\begin{array}{r}+0.015 \\
(+0.04)\end{array}$ \\
\hline
\end{tabular}

Surface change $-0.014,+0.016-0.07,+0.45 \quad 0,+0.024$ limits $(+0.003,+0.07)(-0.07,+0.45)(+0.01,+0$ $\left(m \mathrm{a}^{-1}\right.$ water $)$

Amery-Lambert system. The limits shown are for the worst possible combination of magnitude and sign of the estimated errors, as discussed by Allison (1979). Other than the much-reduced overall budget for the interior drainage basin (+2 rather than $+30 \mathrm{Gt} \mathrm{a}^{-1}$ ), it should be noted that the lower budget limit falls below zero by a significant amount. The errors for the change in surface elevation $\left(-0.014\right.$ to $+0.016 \mathrm{~m} \mathrm{a}^{-1}$ water) allow for the ice sheet to be in balance or actually thinning; this was not the case in any previous budget calculations.

The mass budget for the whole Amery-Lambert drainage system is reduced by $67 \%$ to +14 Gt $a^{-1}$. This represents a mean surface increase of $0.015 \mathrm{~m} \mathrm{a}^{-1}$ water. The lower limit indicates that the entire drainage basin may be in balance while the upper limit is significantly less than previous estimates.

\section{DISCUSSION}

The immediate conclusion of the downward revision of Lambert Glacier's mass balance is to question the possibility of the basin being in a post-surge buildup (Allison, 1979). This contention is supported both 
by the fact that the overall budget is significantly smaller than previous estimates and that the likely limits for the errors actually fall below zero. Although there is geomorphological evidence that ice levels in the Prince Charles Mountains may have fluctuated by several hundred metres in the recent past (Mellor, 1959; Tingey, 1974; Wellman, 1982) and although the results of modelling (Budd and McInnes, [C 1978$]$ ) show that Lambert Glacier is likely to be subject to surging behaviour, the present data do not confirm these suggestions.

Identification of substantial areas of bare ice in the drainage basin of Lambert Glacier must also serve as a warning for the calculation of mass budgets, especially in regions of the Antarctic where data on elevations and accumulation rates are scarce. The possibility of significant local variations in mass balances, as have been found on Mizuho Plateau (Naruse, 1979), makes the extrapolation of accumulation rates over large distances difficult and uncertain. This is particularly true towards coastal regions where slopes are steeper and katabatic winds stronger. Errors in the estimation of discharge from these zones with high accumulation rates will be proportionately more important to calculations of the output of ice from the ice sheet.

Finally, it is possible that the areas of blue ice identified in the Lambert Glacier basin represent a zone of meteorite concentration. Whillans and Cassidy (1983) and Meier (quoted by Williams and others, 1983) identified regions with high vertical strain-rates and high ablation rates as the most likely areas for them to collect. It is possible that the presence of the very irregular subglacial Gamburtsev Mountains and the steep surface slopes resulting in strong katabatic winds may offer suitable conditions to warrant a meteorite collection expedition.

\section{ACKNOWLEDGEMENTS}

I am grateful to Drs D.J. Drewry and G. de Q. Robin for reviews of this paper.

\section{REFERENCES}

Allison, I.F. 1979. The mass budget of the Lambert Glacier drainage basin, Antarctica. Journal of Glaciology, Vol. 22, №. 87, p. 223-35.

Ball, F.K. 1960. Winds on the ice slopes of Antarctica. (In Antarctic meteorology. Proceedings of the symposium held in Melbourne from 18 to 25 February 1959 , arranged by the Australian Bureau of Meteorology. Oxford, etc., Pergmonn Press, p. 9-16.)

Budd, W.F., and McInnes, B.J. [' ${ }^{\text {1978. }}$ Modelling surging glaciers and periodic surging of the Antarctic ice sheet. (In Pittock, A.B., and others, ed. Climatic change and variability: a southern perspective. Editors: A.B. Pittock, L.A. Frakes, D. Jenssen, J.A. Peterson, J.W. Zillman. Cambridge, etc., Cambridge University Press, p. 228-33.)

Budd, W.F., and others. 1967. The Amery Ice Shelf, by W.[F.] Budd, I.[H.] Landon-Smith, and E. [R.] Wishart. (In Jura, H., ed. Physics of snow and ice: international conference on low temperature science.... 1966.... Proceedings, Vol. 1, Pt. 1. [Sapporo]: Institute of Low Temperature Science, Hokkaido University, p. 447-67.)

Bul1, C.B.B. 1971. Snow accumulation in Antarctica. (In Quam, L.0., ed. Research in the Antarctic. A symposium presented at the Dallas meeting of the American Association for the Advancement of Science - December 1968. Washington, D.C., American Association for the Advancement of Science, p. 367-421.)

Drewry, D.J. [C 1983 .] The surface of the Antarctic ice sheet. (In Drewry, D.J., ed. Antarctica: glaciological and geophysical folio. Cambridge, University of Cambridge. Scott Polar Research Institute, Sheet 2.)
Drewry, D.J., and others. 1982. Measured properties of the Antarctic ice sheet: surface configuration, ice thickness, volume, and bedrock characteristics, by D.J. Drewry, S.R. Jordan, and E. Jankowski. Annals of Glaciology, Vol. 3, p. 83-91.

Fujii, Y., and Kusunoki, K. 1982. The role of sublimation and condensation in the formation of ice sheet surface at Mizuho Station, Antarctica. Journal of Geophysical Research, Vol. 87, No. C6, p. 4293300.

Fujiwara, K., and others. 1971. Survey and some considerations on the Antarctic ice sheet, [by] K. Fujiwara, S. Kakinuma, and Y. Yoshida. (In Murayama, M., ed. Report of the Japanese traverse Syowa - South Pole 1968-1969. Tokyo, Polar Research Center, National Science Museum, p. 30-48. (Japanese Antarctic Research Expedition. Scientific Reports, Special Is sue No. 2.))

Giovinetto, M.B. 1964. The drainage system of Antarctica: accumulation. (In Mellor, M., ed. Antarctic snow and ice studies. Washington, D.C., American Geophysical Union, p. 127-55. (Antarctic Research Series, Vol. 2.))

Giovinetto, M.B. [1970.] The Antarctic ice sheet and its probable bi-model response to climata. [Union Géodésique et Géophysique Internationale. Association Internationale d'Hydrologie Scientifique.] [International Council of Scientific Unions. Scientific Committee on Antarctic Research. International Association of Scientific Hydrology. Commission of Snow and Ice.] International Symposium on Antarctic Glaciological Exploration (ISAGE), Hanover, New Hampshire, U.S.A., 3-7 September 1968, p. 347-58. [(Publication No. 86 [de 1'Association Internationale d'Hydrologie Scientifique].)]

Kotlyakov, V.M., and others. 1974. Novaya karta pitaniya lednikovogo pokrova Antarktidy [New map of the accumulation on the Antarctic ice sheet]. [By] V.M. Kotlyakov, N.I. Barkov, I.A. Loseva, V.N. Petrov. Materialy Glyatsiologicheskikh Issledovaniy. Khronika. Obsuzhdeniya, Vyp. 24, p. 248-55.

Levanon, N. 1982. Antarctic ice elevation maps from balloon altimetry. Annals of Glaciology, Vol. 3, p. 184-88.

Mellor, M. 1959. Ice flow in Antarctica. Journal of Glaciology, Vol. 3, No. 25, p. 377-85.

Mellor, M. 1964. Remarks concerning the Antarctic mass bal ance. Polarforschung, Bd. 5, Jahrg. 33, Ht. $1-2,1963$, p. 179-80.

Morgan, V.I. 1972. Oxygen isotope evidence for bottom freezing on the Amery Ice Shelf. Nature, Vol. 238, No. 5364, p. 393-94.

Morgan, V.I., and Budd, W.F. 1975. Radio-echo sounding of the Lambert Giacier basin. Journal of Glaciology, Vol. 15, No. 73, p. 103-11.

Naruse, R. 1979. Thinning of the ice sheet in Mizuho Plateau, East Antarctica. Journal of Glaciology, Vol. 24, No. 90, p. 45-52.

Parish, T.R. 1981. The katabatic winds of Cape Denison and Port Martin. Polar Record, Vol. 20, No. 129, p. 525-32.

Robin, G. de Q. 1983. Coastal sites, Antarctica. (In Robin, G. de Q., ed. The climatic record in polar ice sheets: a study of isotopic and temperature profiles in polar ice sheets based on a workshop held in the Scott Polar Research Institute, Cambridge. Cambridge, etc., Cambridge University Press, p. 118-22.)

Shimizu, H. 1977. Corrected result of altimetric surveys of ice sheet surface made in 1969-1975. (In Watanabe, 0., ed. Glaciological research program in Mizuho Plateau - west Enderby Land, East Antarctica. Pt. 4, 1974-1975. Tokyo, National Institute of Polar Research, p., 170-82. (Japanese Antarctic Research Expedition. JARE Data Reports, No. 36 (Gl aciology).)

Tingey, R.J. 1974. Australian geological mapping of the Prince Charles Mountains, 1968-73. Polar Record, Vol. 17, No. 107, p. 150-53. 
Wellman, P. 1982. Surging of Fisher Glacier, eastern Antarctica: evidence from geomorphology. Journal of Glaciology, Vol. 28, No. 98, p. 23-28.

Whillans, I.M., and Cassidy, W.A. 1983. Catch a falling star: meteorites and old ice. Science, Vol. 222, No. 4619, p. 55-57.

Williams, R.S., jr, and others. 1983. Blue ice, meteorites, and satellite imagery in Antarctica, by R.S. Williams, Jr, T.K. Meunier, and J.G. Ferrigno. Polar Record, Vol. 21, No. 134, p. 493-96.
Yokoyama, K. 1978. Distribution of surface structures of the ice sheet in Mizuho Plateau. (In Ishida, T., ed. Glaciological studies in Mizuho Plateau, East Antarctica, 1969-1975. Tokyo, National Institute of

Polar Research, p. 26-36. (Memoirs of National Institute of Polar Research. Special Issue No. 7.))

Zwally, H.J., and Gloersen, P. 1977. Passive inicrowave images of the polar regions and research applications. Polar Record, Vol. 18, No. 116, p. 431-50.

MS. received 27 January 1984 